\title{
Modern architecture of Saigon - Ho Chi Minh City
}

\author{
Hai Thanh Truong ${ }^{1, *}$ and Thi Hong Hanh $\mathrm{Vu}^{2}$ \\ ${ }^{1}$ Center of International Training, University of Architecture Ho Chi Minh City, 196 Pasteur, District \\ 1, Ho Chi Minh City, Vietnam \\ ${ }^{2}$ Department of Architecture, University of Architecture Ho Chi Minh City, 196 Pasteur, District 1, \\ Ho Chi Minh City, Vietnam
}

\begin{abstract}
Saigon - Ho Chi Minh City (HCMC) with its 300 years of development has resulted in diverse architecture in terms of types and styles, of which modern architecture is somehow less concerned and sometimes neglected. This research is aimed to take a survey on Modern Architecture in Saigon-HCMC in order to list valuable ones that need attention to the development related to their values.
\end{abstract}

\section{Introduction}

Regarding modern architecture because of its recent existence of the $20^{\text {th }}$ century, a little attention is paid to protection of its values in many places, including Vietnam. MASEANa project is one of the efforts to recognize and somehow draw attentions on modern building heritage protections in ASEAN countries, including Vietnam. In Vietnam, Hanoi and Ho Chi Minh City were chosen to undertake the survey aiming at listing initially valuable modern buildings which are likely under threats of neglect ion and demolitions due to rapid urbanizations and aggressive developments [1].

In 2002, a research on architecture in Ho Chi Minh City after 1986 was carried out by a group of lecturers of Architecture Department, University of Architecture HCMC. That research identified, reviewed, and analyzed typical buildings representing architecture in 25 years after Doimoi (reformation) 1986 in HCMC. However, in relation to modern architecture of this city which started since the beginning of the 20th century, this research only covered the later period $[1,2,3]$.

The current paper briefly analyses the transformation of modern architecture in different historic periods of time of Saigon HCMC. This helps to provide bases for a survey aiming at building up an inventory for Modern Architecture in Saigon-HCMC. As architecture is a product of certain economical, ideological, social-cultural, political contexts and personal inputs of architects/designers, to understand architecture, those contexts also need to be referenced. Then based upon the framework of analyzing architectural values, this research recommends a list of valuable buildings according to different categories of values and their levels. The result of this research is an initial starting point for a longer term of redefining Modern Architecture Heritage in Saigon-HCMC and in Vietnam generally.

\footnotetext{
${ }^{*}$ Corresponding author: thanhhai_truong@yahoo.com
} 


\section{Literature review}

\subsection{Brief History [1-6]}

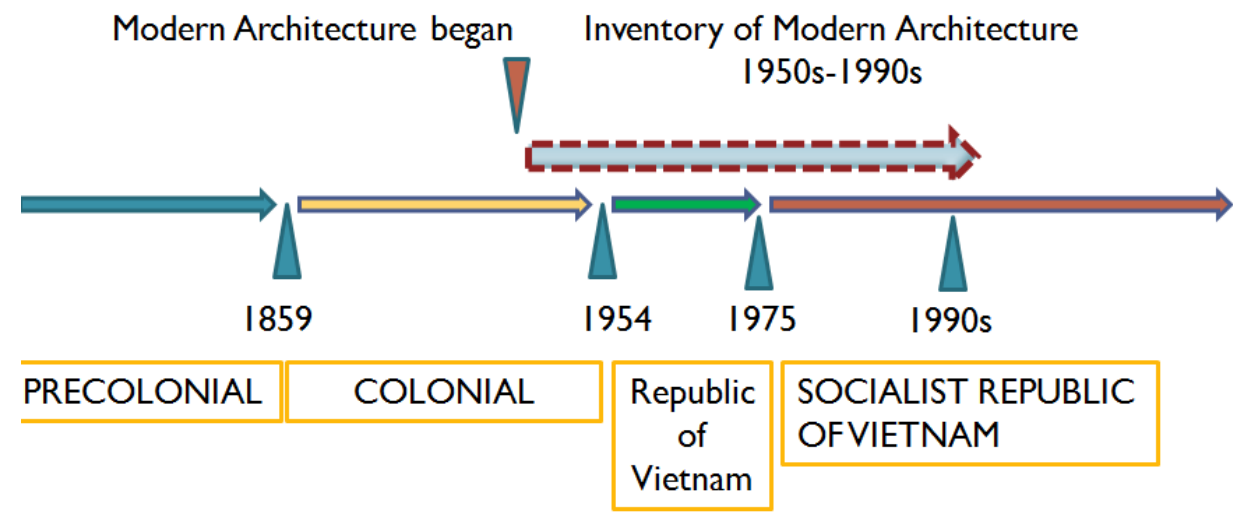

Fig. 1. Timeline of Saigon-HCMC history of development and relationship to Modern Architecture $[1,5,6]$.

\subsubsection{Pre-colonial architecture}

In Saigon-HCMC, the remains of pre-colonial architecture are quite rare to find today. However, there are still represented the great references to an entire systems of citadel, forts, pagodas, temples, markets, and hamlets of the far South under Nguyen Dynasty, evidenced in scattered temples, pagodas, citadel's walls and gates, etc [1,5,6,7] (see Fig 2).

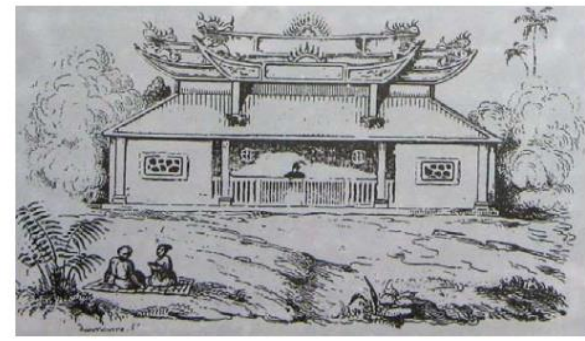

A Viet's temple in Saigon, drawn in the 1800 s

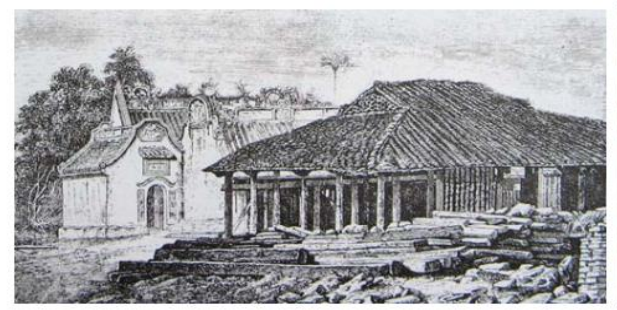

Pagoda and house in Saigon (Catinat street - known as Đồng Khởi), Drawn in 1864

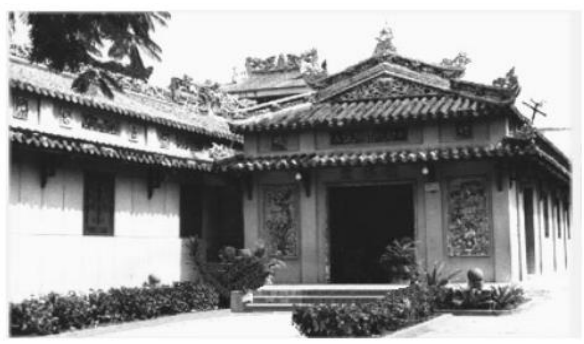

Le Van Duyet temple, a purely traditional area, from the buildings, spatial layout and uses.

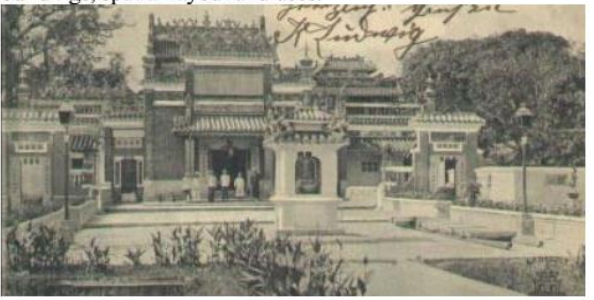

Chinese pagoda in Saigon built in the 1800 s, photo taken in French colony, a popular postcard in the $1890 \mathrm{~s}-1900 \mathrm{~s}$ 

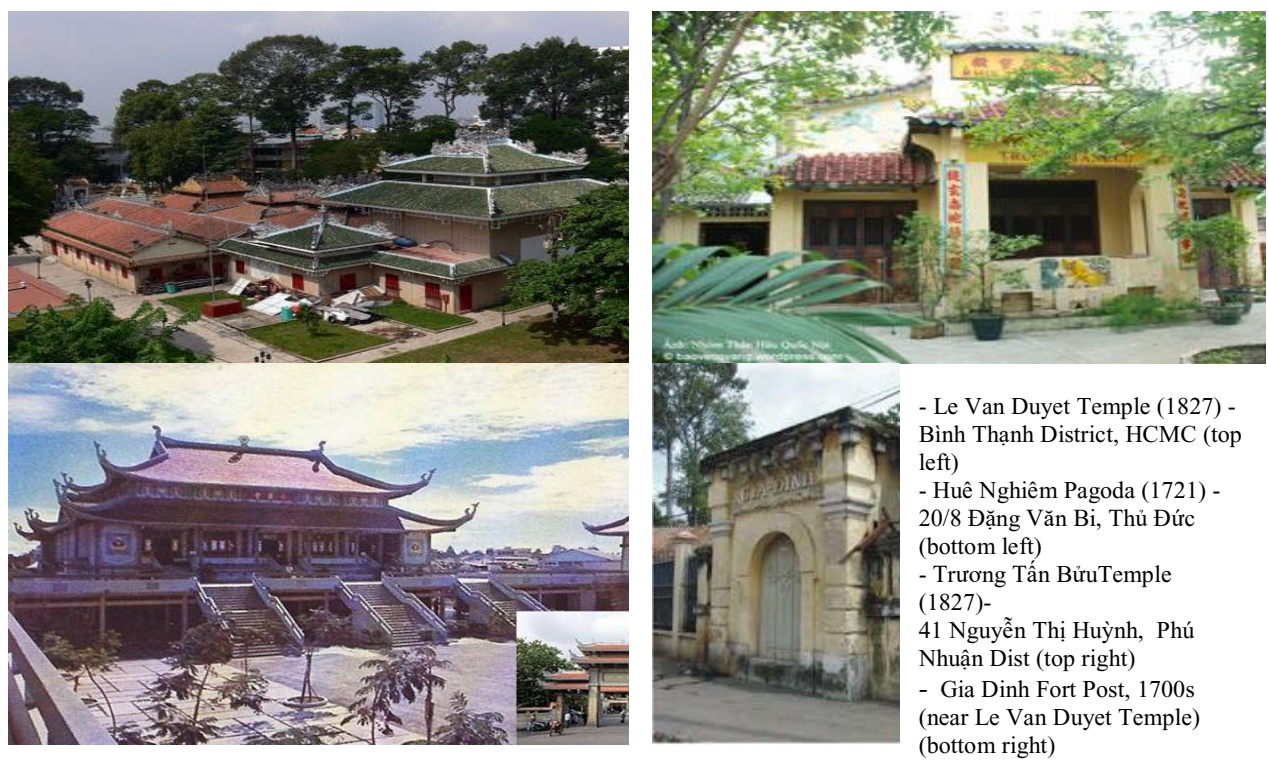

Fig. 2. Different religious buildings constructed for different ethnic communities in Saigon during 1800 s $[5,7]$.

\subsubsection{Colonial architecture}

On the contrary, French colonial Architecture is easily seen all around the city, from the grid street pattern, urban structure with parks, botanic gardens and squares, to all kind of buildings such as administrative, medical, educational, residential, religious, and so on. The styles are varied from the purely copy of popular western Neo Classical, Beaux-Arts, Art Décor (1860s1900s; with City Hall, Petrus Ky school, the History Museum) to a more culturally and climatically adaptive (Indochina) architecture (1900s-1950s), with which the Expressions of eclecticism styles with Khmer, Cham, Chinese and Viet details was quite popular (Indochina bank). Many of them remain heritage today. Unfortunately, not many were designed by Vietnamese architects although first school of architecture École Supérieure des Beaux Arts de l'Indochine had been founded during 1925-1945 [5,6].

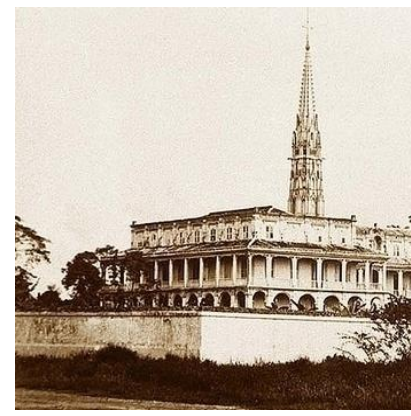

Saint Paul Abbey, designed and built by Nguyen Truong To in $1860 \mathrm{~s}$ (right) and today (left) [1]

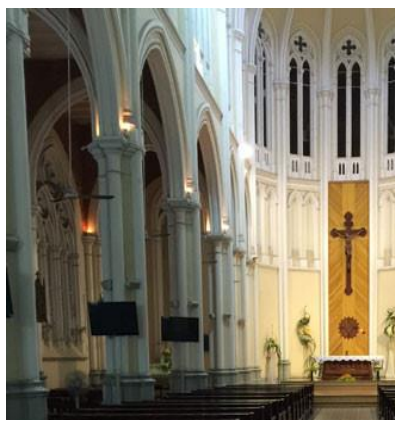

History Museums, effort to research and exhibit Indochina culture (1900s) 


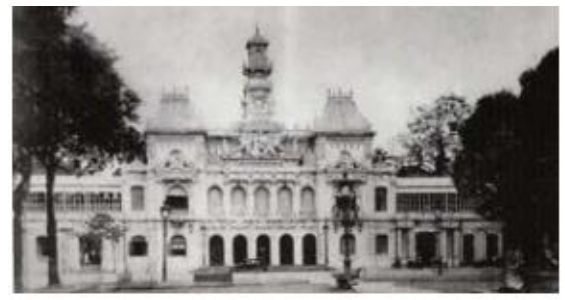

The city hall (1918)

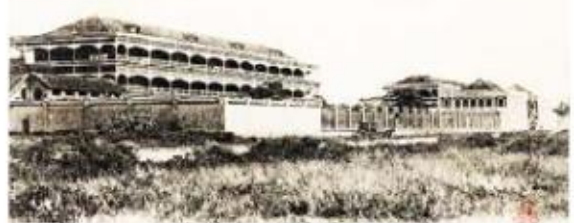

A barrack in Norodom Blv
Justice Office

Fig. 3. Expressions of eclecticism styles: the pure classical in Saigon during 1860s-1900s [1,5,6,7].

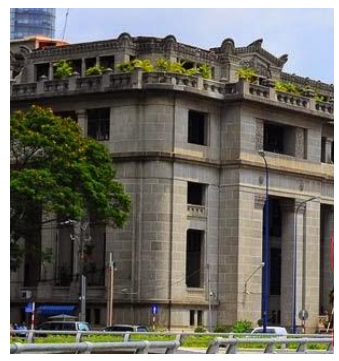

Indochina Bank

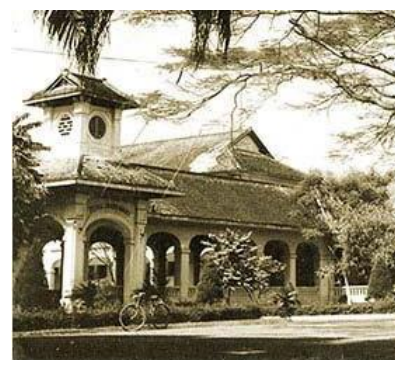

Petrus Ky High school

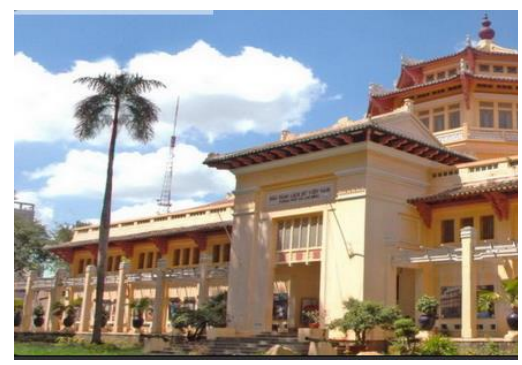

History Museum

Fig. 4. First 'localized' architecture in Saigon during 1920s with expressions of eclecticism styles with Khmer, Cham, Chinese and Viet details $[5,6]$.

\subsubsection{Modern architecture in Saigon - republic of Vietnam 1954 -1975 [1,5,6,8-12]}

The contexts:

- Inherited French urban planning, buildings design and constructions;

- The emerge of new lifestyles and financial support from American, yet strongly influenced by the French;

- The development of architecture-related industries such as construction material industries, fine arts;

- The Nationalism of Republic of Vietnam government as well as Vietnamese professional idealism;

- The emerge of the first generation of Vietnamese architects trained in France, United State and locally;

- Influences of Modern Architecture Movement from the West and United State, with Modern Architectural expressions [4,5,6,8,9,10]:

- Form follow function"

- Asymmetrical compositions

○ Use of general cubic or cylindrical shapes

- Flat roofs

- Use of reinforced concrete

- Metal and glass frameworks often resulting in large windows in horizontal bands

- Absences of ornament or moldings

Pioneering buildings and architects of Saigon in 1950s-1970s [1,5,6].

Vietnamese architects who studied at École Supérieure des Beaux Arts de l'Indochine, as well as Écoles des Beaux-Arts in Paris, such as Ngô Viet Thu, Nguyen Huu Thien, Nguyen Quang Nhac, Tran Dinh Quyen, Nguyen Ba Lang, Huynh Tan Phat, etc. have placed very important roles in contextualizing international modern movement of architecture into Saigon. Their outstanding buildings such as Independent Palace, Agriculture University, General Science Library, Thị Nghè Church, Institute of Cultural Exchange with France 
(IDECAF), Thống Nhất (Vì Dân) Hospital, Vĩnh Nghiêm pagoda, and Submarine Force Office (today Prime Minister Office No2) have been nationally recognized. They have contextualized Western modern Architecture to a Saigon tropical climate, and at the same time been responsive to national traditional aesthetic perceptions. As a result, their buildings bear local identity, yet still internationally modern.

Although there are some differences on their appearances, the design of these buildings usually focused on the logic relations between forms and functions, as well as the solutions for the city special tropical climate. This is why they are called "Modern Tropicalization Architecture".

Table 1. Pioneering Architects and their buildings in Saigon-HCMC in 1950s-1970s [1,5,6].
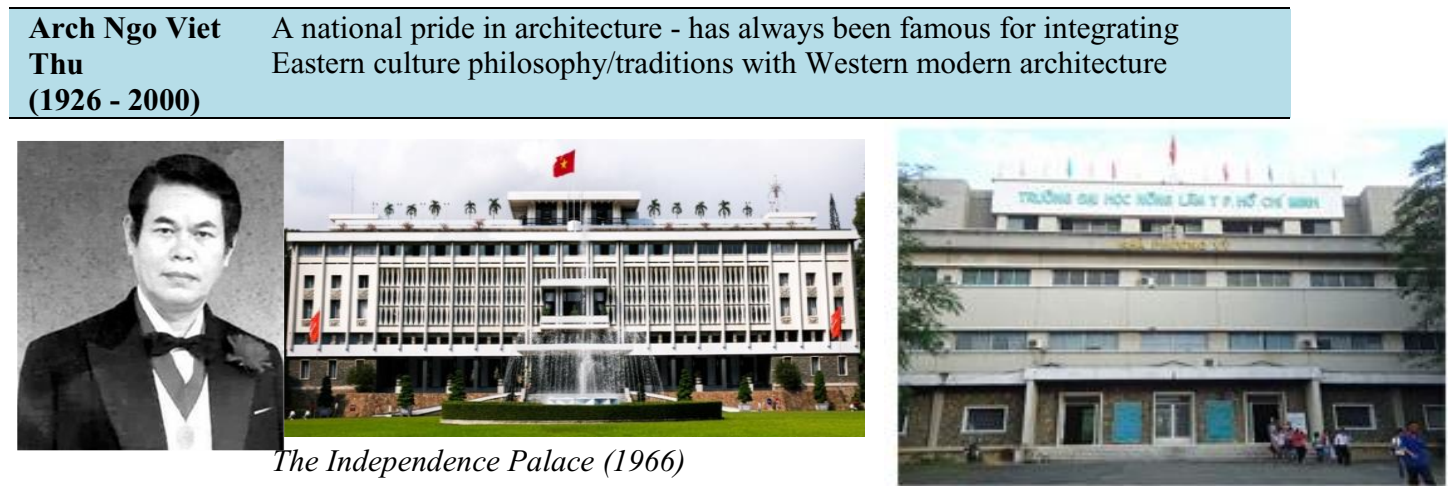

Agriculture university (1970s)

\begin{tabular}{ll}
\hline $\begin{array}{l}\text { Arch Nguyen } \\
\text { Huu Thien } \\
\text { (1914-1981) }\end{array}$ & $\begin{array}{l}\text { Modern buildings with traditional decorative patterns, integrated with } \\
\text { surrounding landscape }\end{array}$ \\
\hline
\end{tabular}

(1914-1981)

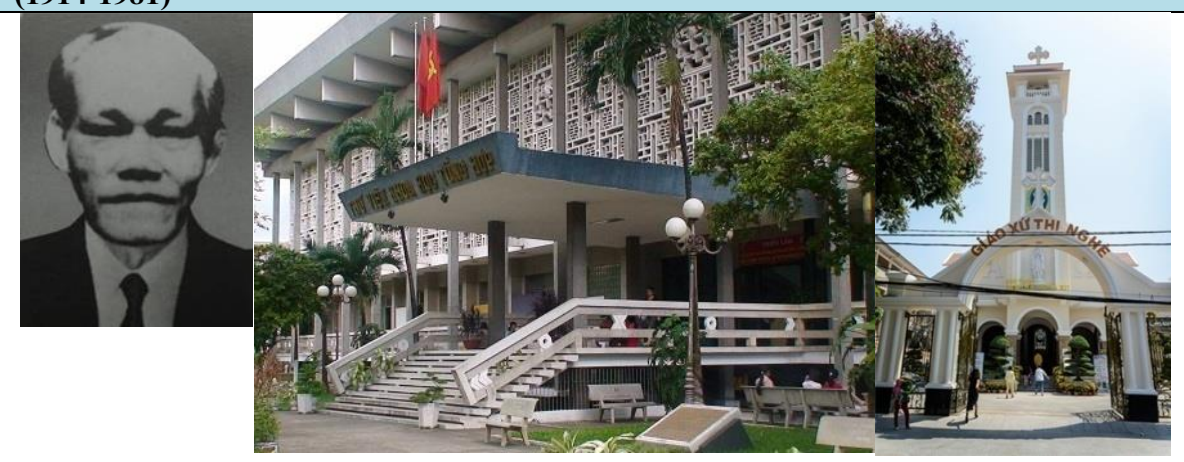

General Sciences Library (1955)

Thi nghe Church

Arch Huynh (1913-1989), worked sucessfully in both periods before and after 1975

Tan Phat 


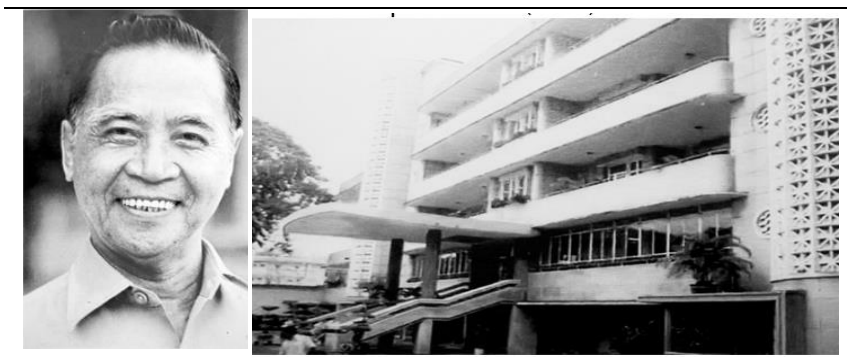

Submarine Force Office (before 1975)

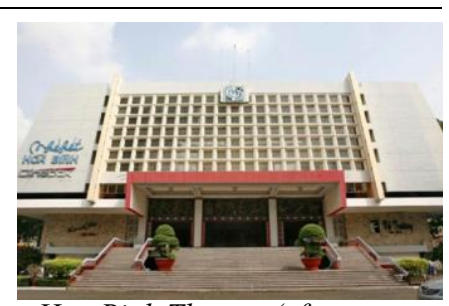

Hoa Binh Theatre (after 1980s)

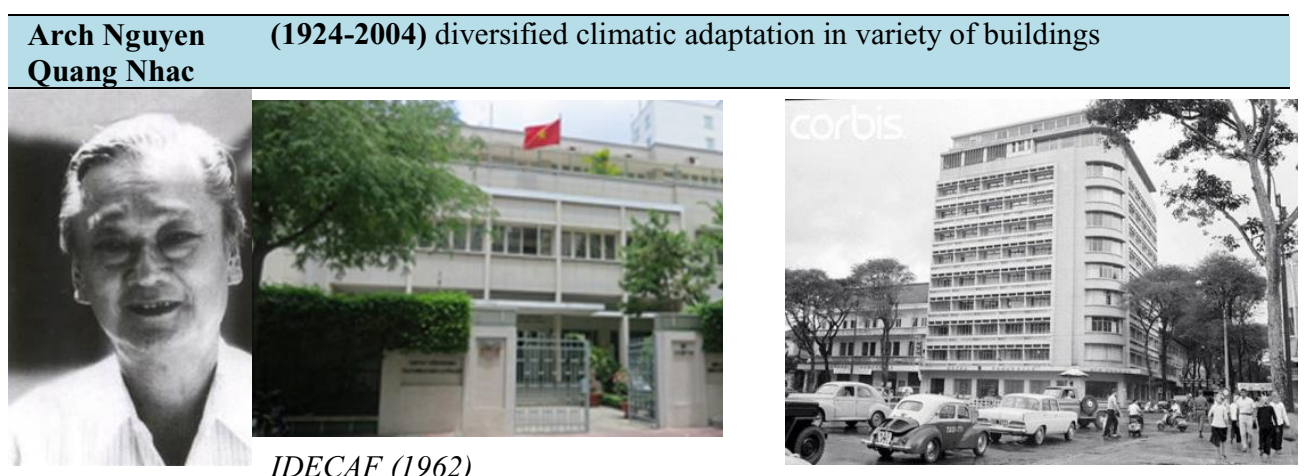

Caravelle Hotel

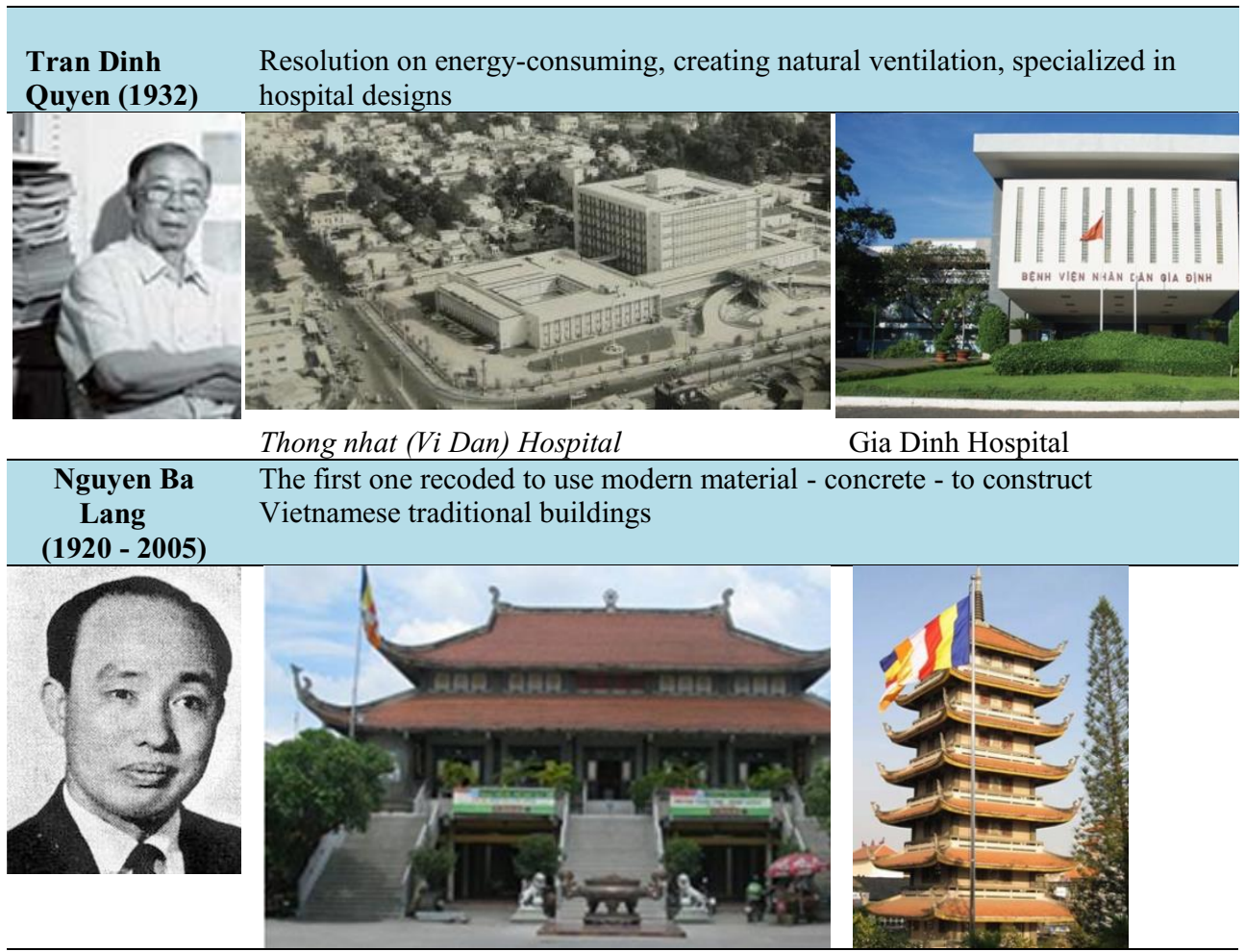

Vinh Nghiem pagoda (1971) 


\subsubsection{Modern architecture in saigon - socialist republic of vietnam 1975 - 1990s $[1,2,5,6]$}

After 1975, the nation was unified, the city changed into a new period. Architecture was continuiously inherited and influenced by Architecture of previous periods of time, at the same time, constitutively followed the popular styles of communist countries, particularly Soviet Union (Liên Xô).

- Continually influenced by Architecture of Saigon before 1975:

○ Uses of cluastra

- Diversify and simplify traditional timber structure by concrete consoles

- Functionalism: mainly applied to public buildings such as hospitals, factories

- Influenced by the popular styles of communist countries in particular Soviet Union (Liên Xô), with a number of architects trained from communist countries and the north coming to practice in Saigon -HCMC :

- Architecture as a Sculpture (Hoa Binh Theatre)

- Functionalism - concept of Communalism (XHCN) (Cultural House Dist 5)

- Socialist Expressionism (Phan Dinh Phung Indoor Stadium, demolished in 2017)

However, due to financial constraint and available of existing urban facilities, not many buildings were built until after 1986. From 1986, the city with its new socialist-oriented market economy has formed the new face of architecture with variety of modernism as well as post modernism architectural styles.

\section{Materials and methods}

Research questions:

- $\quad$ How valuable are Modern Building in Saigon HCMC?

- How are they recognized?

The survey: Facts and figures reviewed

Area: 12 districts, according to administrative map of 1990s, 1600 buildings

Participants: 4 lecturers of UAH, from Planning department and Architecture department , 19 students from Urban design discipline, 30 students from Urban Planning Department, experts from different institutions internationally and locally;

- $\quad$ Time: 2 months surveying, with 10 workshops and group discussions

- 50 buildings listed for the first stage

- 40 buildings listed for the second stage

What to evaluate?

Based on 'what defines space/places' (Fig 5) as Physical form, the functions and meanings to relevant people, the research analyses the values. Values are quantified from 0 to 5 points max. While the Architectural forms/ features and Functions of buildings are possibly professionally evaluated by experts via workshops and discussions, the meanings to relevant people need participation of stakeholders, who include owners, users, and affecting people living and involving inside and nearby. 


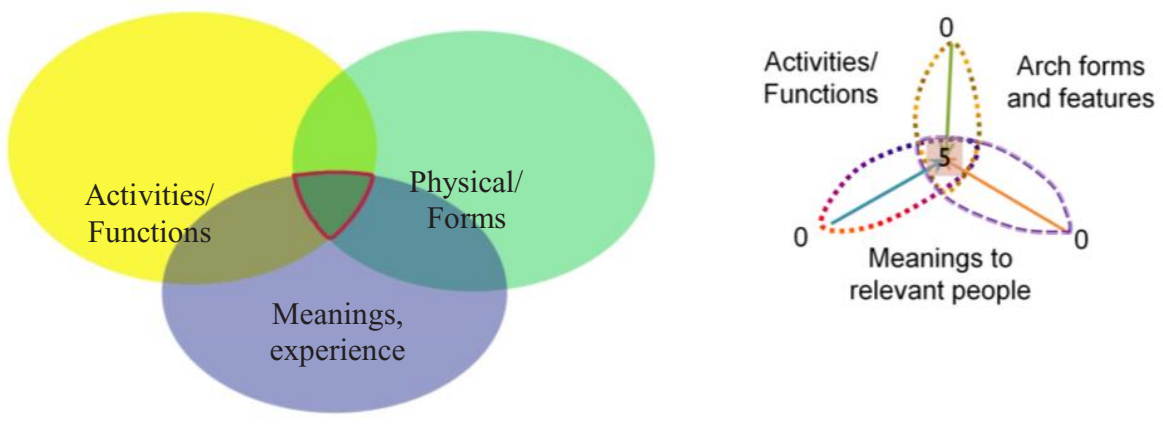

Fig. 5. Dinemesions of space/place $[5,6,13,14]$.

How to evaluate:

- $\quad$ First stage: Review the 1600 buildings in 12 districts (according to Administrative Map in 1990) to find out how valuable in terms of Physical forms and functions/activities

- Initially chose buildings that have valuable arch forms and features; how the building in general and different architecture elements separately are in different statuses of (1) stability, and (2) 'aestheticism';

- Map out their functions/activities and evaluate levels of (1) utilities and (2) how these uses have transformed in different times, the more layers of uses, the more valuable; and (3) the possibility of being used in the future, the more likely the more valuable;

This step is in formats of workshops, seminars, discussions among professionals, Arch students and advisors from mASEANa projects: Dr Shin and Yamana from Tokyo university of Technology

List of about 50 buildings is shortlisted for the second stage'

- The second stage: Review and evaluate the 'emotional aspect' of spaces: what do these buildings mean to people?

A survey collecting data regarding stakeholders on how have they been attached to buildings; participants are those who live, use, see, own, the building daily. Their opinions on the building regarding the two other aspects of spaces that already given values in the first stage are also tested; The new input help strengthen/or question/examine the first stage results;

Unfortunately, this second stage has not done well with all stakeholders due to time constraints and lack of financial supports; only few buildings are taken to the survey. However, the result reflex quite accordingly to the 1 stage;

According to average marks/point given to each building, they are put in list in descending order.

\section{Results}

This section analyses two components of the research, which include (1) the analytical analysis of modern building morphologies in Saigon - HCMC in two periods (before and after 1975) and (2) the list of buildings recommended based upon the values given to each one.

\subsection{SURVEY RESULT- the analytical analysis of modern building morphologies in Saigon - HCMC}

The majority of Modern Building reviewed and Listed in Saigon HCMC are of 1950s-1970s 


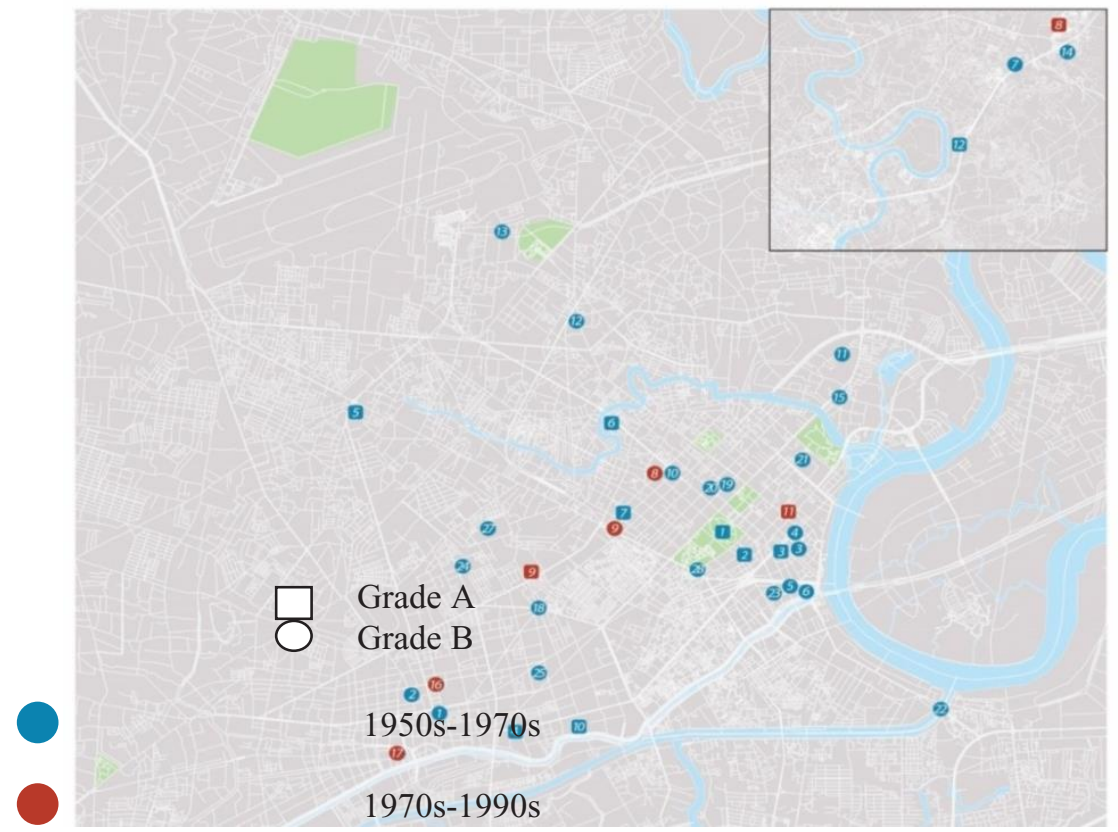

Fig. 6. Locations of Modern buildings listed in Saigon - HCMC [1].

\subsubsection{There are similarities, yet a few differences between Modern Buildings before and after 1975}

\begin{tabular}{|c|c|c|}
\hline Building styles & Before 1975 & After 1975 \\
\hline 1. French colonial Architecture with contextual elements & $\mathrm{x}$ & $\mathrm{x}$ \\
\hline 2. New building designs and constructions & $\mathrm{x}$ & $\mathrm{x}$ \\
\hline 3. Pure Functionalism & $\mathrm{x}$ & $\mathrm{x}$ \\
\hline $\begin{array}{l}\text { 4. Neo expressionisms: } \\
\text { Architecture as sculpture } \\
\text { Socialist expressionism }\end{array}$ & & $\mathrm{x}$ \\
\hline
\end{tabular}

a) The Similarities

- Modernism trend with tropical climatic adaptive elements/solutions

To provide shading and protect inside spaces from sunlight: uses of claustra (louvers), side corridor or extended roof;

To cool the air and create natural ventilations: wind- oriented building directions (Southward), Elevated the ground floor, double layer door/window, courtyard/lightwell in between buildings.

- Modernism with traditionalism explorations:

- Diversify and simplify traditional timber structure with concrete console and flat roof;

- Detailed patterns, simplified traditional timber structure

- Pure Functionalism: applied strictly to Factories, schools, hospitals 


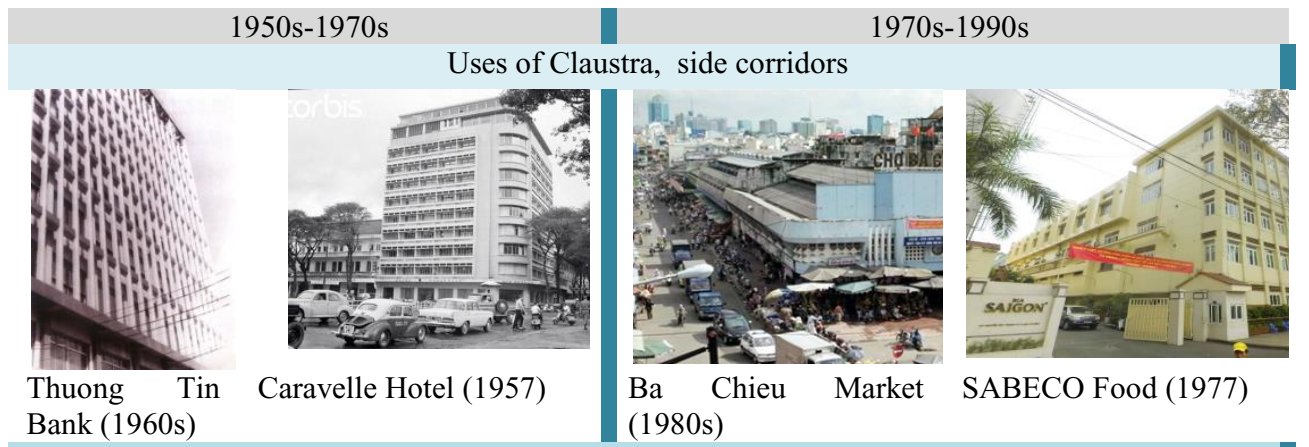

Bank (1960s)

(1980s)

Diversify and simplify traditional timber structure with concrete console and flat roof

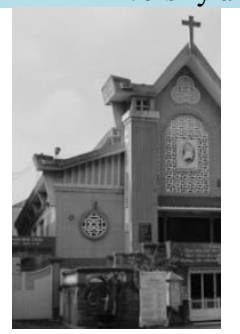

Nguyen Duy Khang Church (1955)

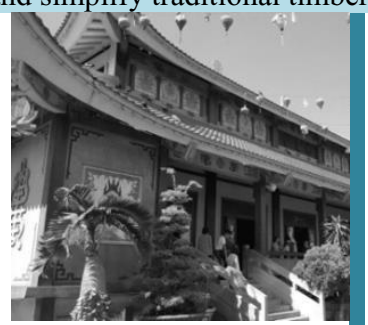

Vinh Nghiem Pagoda (1957)

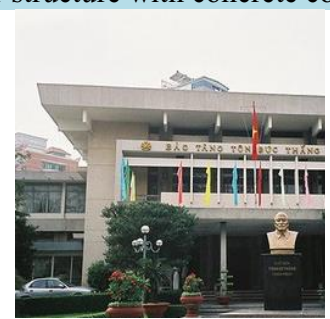

Ton Duc Thang Museum (1998)

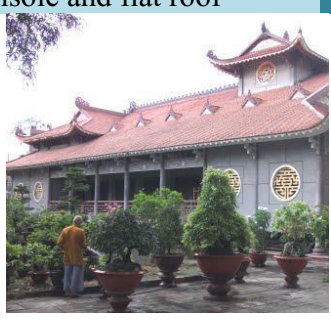

Hue Nghiem Pagoda, Binh Chanh by Arch Vo Dinh Diep (1977)

\section{1) Detaile \\ General Sciences Library (1967)
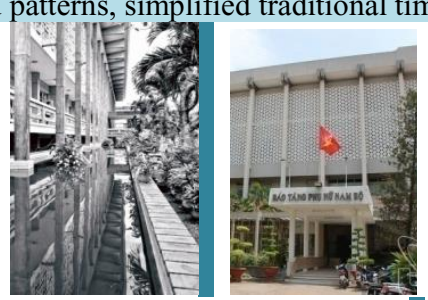 \\ Women Museum (1985)

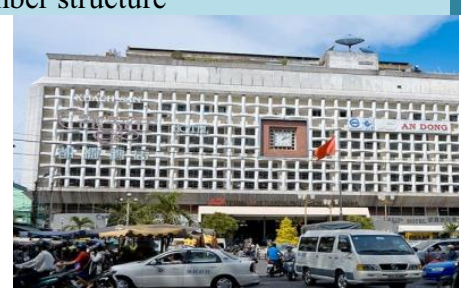 \\ An Đông Market (1980s), by Arch Lê Văn Rọt}

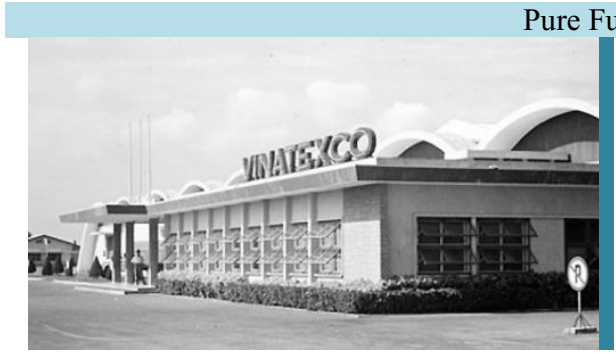

Thang Lợi Textile Co today (1960s)

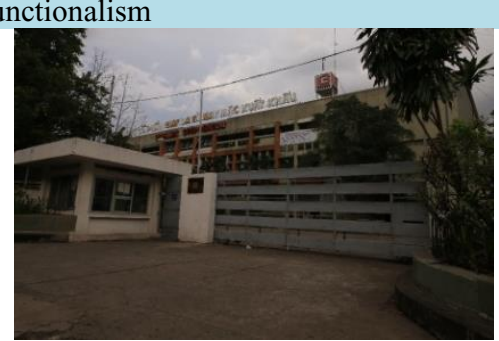

Legamex Coporation (1986)

Fig. 7. The similarities of Modern Buildings before and after 1975 [1,5,6].

b) The differences of Modern Architecture in Saigon-HCMC after 1975 compared to those before 1975

In this period, due to economic and political constraints, not many buildings were built in the South of Vietnam, rather, to reuse and take advantage of existing facilities. Rare buildings were built in hardships, with New/neo expressionism of either $[1,5,6]$ :

Architecture as a Sculpture

- Functionalism - socialist expressionism (XHCN), Soviet influences 


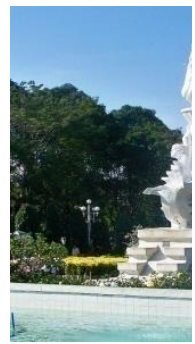

Sculpture in Lê Văn Tám park

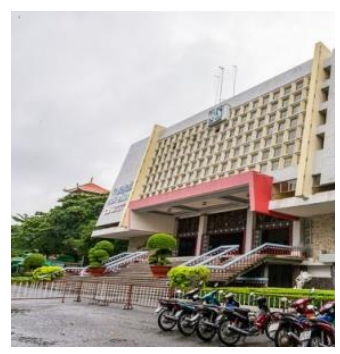

Hoa Binh Theatre (1985), Modernism with Soviet influences

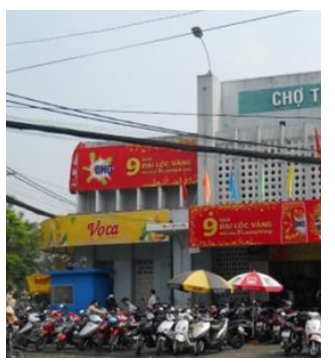

Thai Binh Market

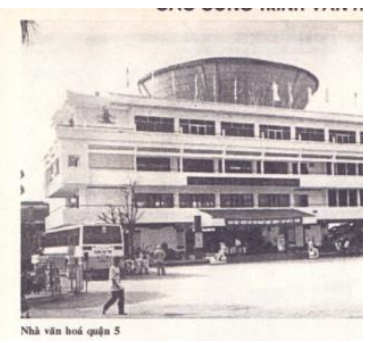

Dist 5 Culture House

Fig. 8. The differences of Modern buildings in Saigon-HCMC after 1975 compared to those before $1975[1,2,5,6]$.

\subsection{Modern Building Heritage in Saigon-HCMC - the Possibility}

The research lists 40 buildings, but not in the same categories due to the big difference of values. Therefore, two grades are classified: A and B. Grade A (30\%) are those buildings which receive above 4 out of 5 points in three dimensional values of space; grade B are the buildings $(70 \%)$ which receive between 3-4 points out of 5 points given to all three dimensions (see Fig 6 above). The order of the buildings is based upon the total points given to three categories.

The building typologies are also varied from public facilities, religious, private properties, to factories and infrastructure like bridges.
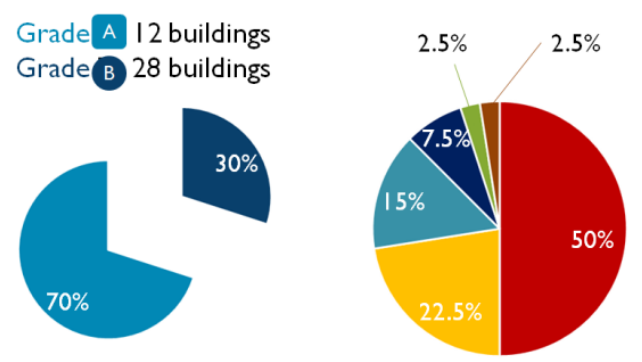

- Public facilities
Religious

- Private property

- Industrial

Infrastructure

- Other

Fig. 9. Ratio and typologies of buildings listed $[1,5.6]$.

The list and images of those buildings are in Tables 2 and 3 below:

Table 2. Grade A buildings listed $[1,5,6]$.

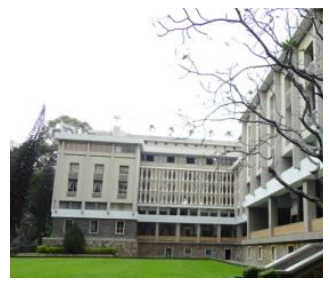

1. Independence palace (1966) - dist. 1

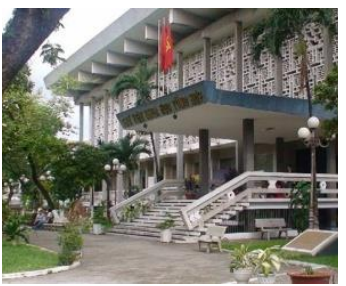

2. General sciences library of hemc (1955) dist.1

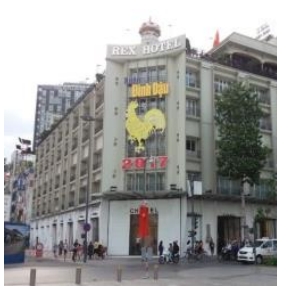

3. Rex hotel (1927| 1959) - dist. 1

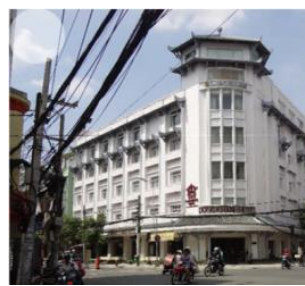

4. Dong khanh hotel (1960s) - dist.5 


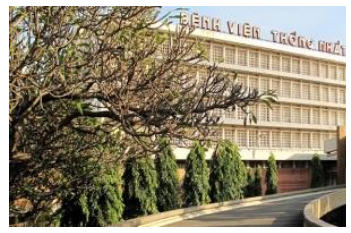

5. Thong nhat hospital tan binh dist

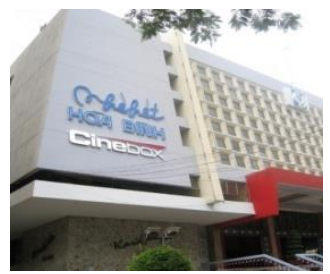

9. Hoa binh theatre (1980) - dist.10

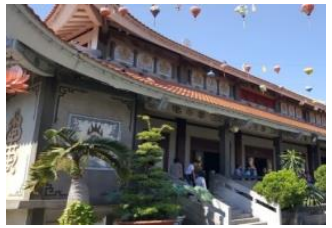

6. Vinh nghiem pagoda (1971) - dist.3

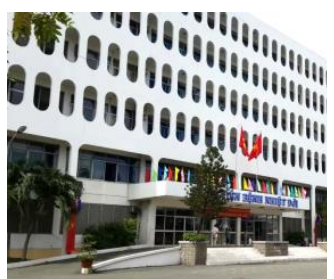

10. Hospital of tropical diseases (1973)

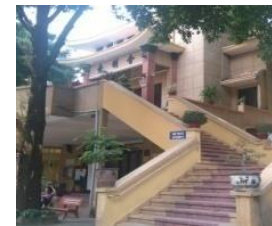

7. Xa loi pagoda (1958) - dist.3

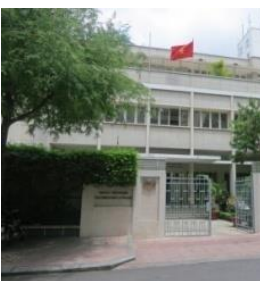

11. Institute of cultural exchange with france (1982) - dist.1

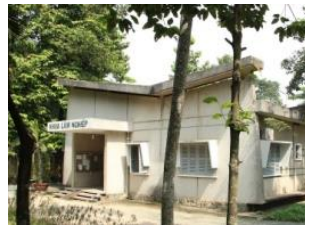

8.agriculture and sylviculture university - thu duc dist.

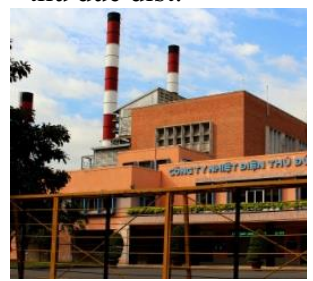

12. Thu duc

thermoelectric plant

(1965) - thu duc dist.

Table 3. Grade B buildings listed $[1,5,6]$.

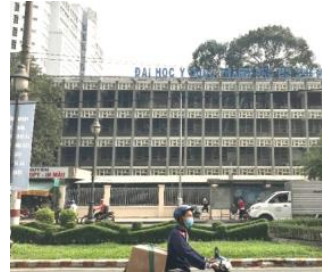

1. University of

medicine and

pharmacy (1966) -

dist. 5

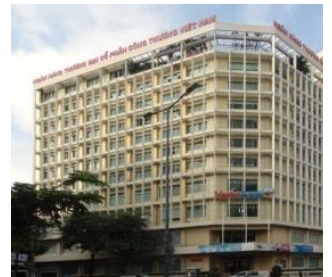

5. Vietinbank (before 1975) - dist.1

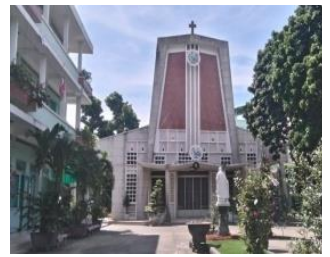

9. Mai khoi parish (1975) - dist.3

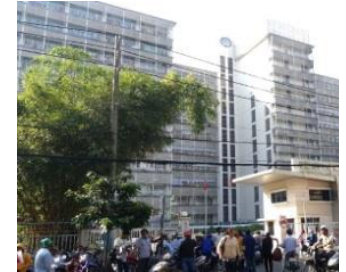

2. Cho ray hospital dist.5

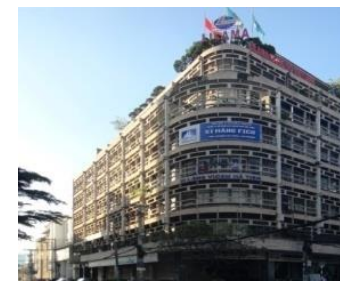

6. Fico headquater dist. 1

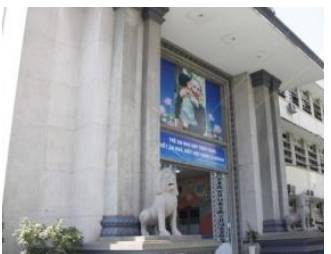

10. Children cultural house of dist.3

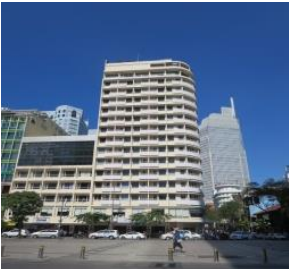

3. Palace hotel

(1971) - dist. 1

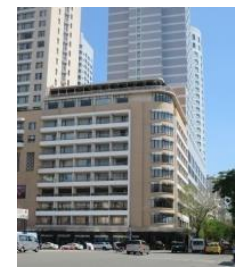

4. Caravelle hotel (1957) - dist. 1

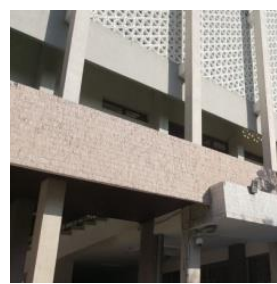

8. Southern women museum (1985) dist.3

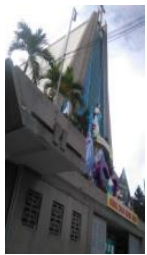

11. Nguyen duy

12. Phat diem parish (1955) - phu nhuan dist. 


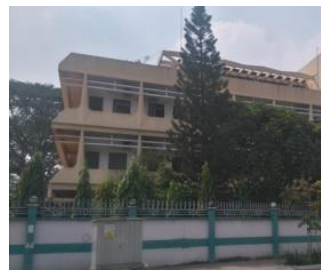

13. Airport coperations of vietnam office

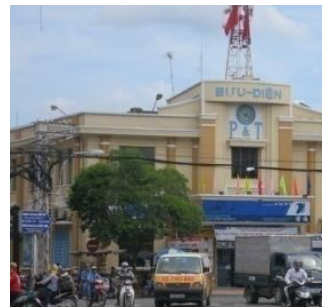

17. District post office (1979 - 1956) - dist.5

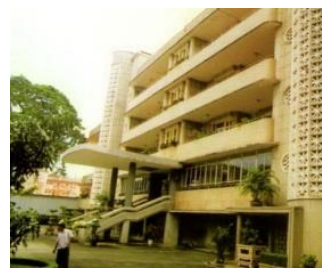

21. Governance office - dist. 1

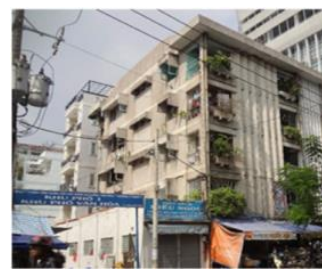

25. Low-rise apartment - dist. 5

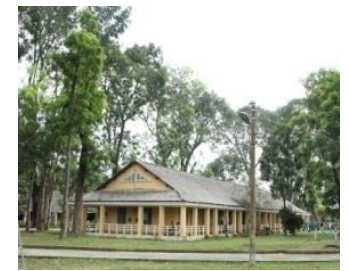

14. Military school thu duc dist.

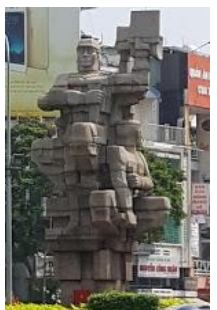

18. Roundabout statue - dist. 1

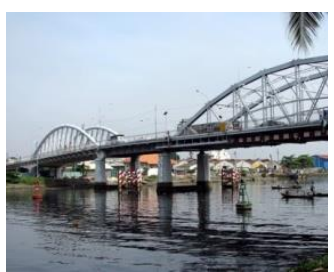

22. Tan thuan bridge dist. $4 \mathrm{x}$ dist. 7

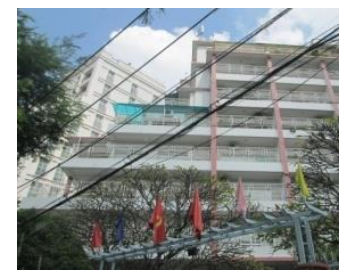

26. Rental housing dist.1

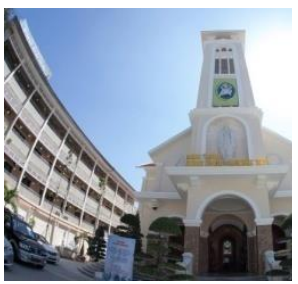

15 thi nghe church (1935) - binh thanh dist.

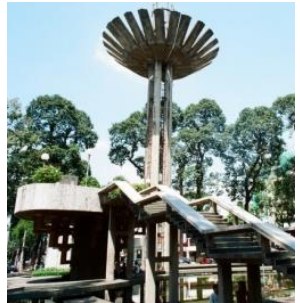

19. Turtle lake (1965) - dist. 1

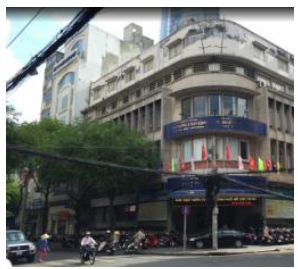

23. Hcmc university of banking - dist. 1

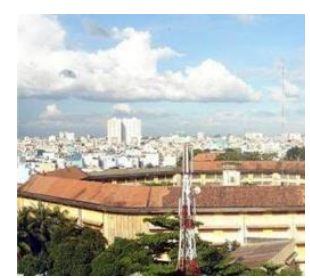

27. Chi hoa prison (1942)-dist.10

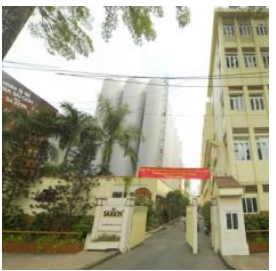

16. Sabeco food \& beverage factory (1977) - dist. 5

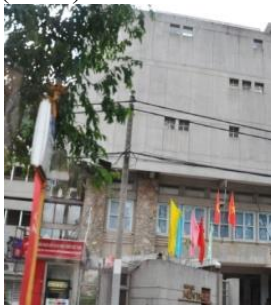

20. Hcmc

university of architecture (1972)

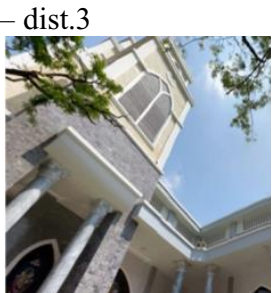

24. Dong tien church (1962 2014) - dist. 10

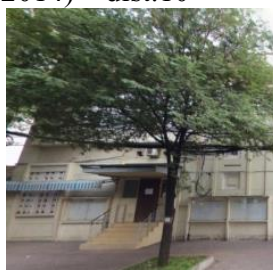

28. Immigration dept management office - dist. 3

\section{Discussions}

It has been evidenced that the research aiming at listing Modern Archtiecture in Vietnam and particularly in Saigon HCMC should have been done long before. However, lately carried out within the framework of joint project with mASEANa. For greater impacts of this research, publications regarding the research and results of the research should be processed to raise awareness and attentions on the values of Modern buildings in Saigon-HCMC, avoiding demolitions and deterioration of the listed buildings whose designers are among first generation of Vietnamese architects. Values regarding forms, materials, detailed patterns that expressed climatic and cultural adaptations, as a result, could be potentially reviewed and applied in contemporary architecture today. 
Further, this research refeclts how traditions and vernacular architectural identity have been diversified via Modern architecture during 1950s-1970s, questions the overwhelming focus on traditional architecture recently without looking back on those time experiences/values. As a result, in most cases, architects are rather imitating traditional patterns than actual values in design contemporary buildings, creating chaotic gaps and confused images of non-sense/non-styles in many places.

As a result of the current research, the list is an initial that need more in-depth evaluations, especially regarding perceptual values on emotional meanings of spaces/buildings. Further research on perceptions of spaces/buildings should be carried out with participations of staheholders.

Based upon the experience and inherence from the current research, similar surveys should be carried out in larger areas, especially in Hue, Dalat (Bao Loc), Can Tho where Modern architecture during 1950s-1990s was developed with political and financial supports of the Southern Government at the time; pioneering architects such as Ngo Viet Thu, Nguyen Huu Thien, Pham Van Thang, Nguyen Ba Lang, etc., while practised in Saigon also designed many great buildings there. Comparative values on similar building typologies/morphologies built in different climatic and social conditions are then analysed and become a great sources of references in Vietnam building design today.

\section{Conclusions}

To conclude, Modern Architecture of Saigon-HCMC, due to rapidly changing historical contexts, has diversified different expressions. Buildings, at the one hand, are functionally and aethetically modern. On the other hand, most buildings focused on (1) exploiting social cultural values, (2) adapting to climatic conditions, (3) and simplifying traditional venacular architectural orientations using concrete and more advanced and available construction materials at that time. These efforts have made Modern Architecture in Saigon-HCMC different from other places in Vietnam, especially from the North of Vietnam. At the same time, given values to the local modern architecture heritage, which can be founded in many buildings, are already listed and recently included in the inventory of Modern Architecture of Saigon-HCMC as part of mASEANa project that University of Architecture Ho Chi Minh City has joined.

\section{Acknowledgements}

Many thanks to Dr Nguyen Cam Duong Ly, Dr Tran Mai Anh, 30 students from Planning Department and 19 students from Urban design Program, University of Architecture Ho chiminh City (UAH) who involved in the survey, working very hard in vey intensive time in order to gather data for this joint research;

Special thanks to mASEANa project, DOCOMOMO International, DOCOMOMO Japan, Tokyo Technology University, UAH, and sponsors who enable this research financially and technically;

Specially thank University of Architecture Ho chiminh City (UAH) and Moscow State University of Civil Engineering (MGSU) in providing support and enable publications of this research.

\section{References}

1. T. H. Truong, A survey on Modern Architecture of Saigon-HCMC (University of Architecture Hochiminh City, 2016) 
2. D.H. Vu et.al., Le Thanh Son, 25 year of Hochiminh City Architecture (University of Architecture Hochiminh City, HCMC, 2002)

3. T. V. Giau, B. Dang, Cultural Geography of Hochiminh City (Hochiminh City Press, HCMC, 1998)

4. Ton Dai, Nguyen Quoc Thong, History of Vietnamese Architecture (Science and Technique Press, Ha Noi, 2015)

5. T. Truong, T.H.H. Vu, Brief History of Modern Architecture in Saigon- HCMC, Conference paper, 2nd mASEANa conference on 'Modern Architecture, the pioneers'(2017)

6. T.H.H. Vu, Canals and Identities of Saigon - Hochiminh City, PhD thesis (Oxford Brookes University, Oxford, 2010)

7. K. Frampton, Modern Architecture, A critical History, fourth edition (Thames \& Hudson Ltd, London, 2007)

8. W.J.R. Curtis, Modern Architecture since 1900, third edition (Phaidon Press Ltd, New York, 1996)

9. S. Kostof, A history of Architecture setting and rituals (Oxford University Press, Oxford, 1985)

10. T. H. Truong, The Quality of Public Open Spaces in Hochiminh City-Vietnam, PhD thesis (Oxford Brookes University, Oxford, 2013)

11. T. Hai Truong, Space and the development of spatial composition in performance buildings, Master thesis (Hochiminh City University of Architecture, HCMC, 2002)

12. T.H.H. Vu, Canal housing and issues of recognition and conservation of spatial values, Conference paper, Canal-side Housing in Hochiminh City (2014)

13. I. Bentley, Responsive Urban Design, International creditated Short Course (University of Architecture Hochiminh city, HCMC, 2012) 